\title{
Physiological ecology of three populations of the bivalve Scrobicularia plana
}

\author{
C. M. Worrall, J. Widdows and D. M. Lowe \\ Institute for Marine Environmental Research, Prospect Place, The Hoe, Plymouth PL1 3DH, United Kingdom
}

\begin{abstract}
Seasonal cycles in rates of oxygen consumption, clearance, ammonia-nitrogen excretion and absorption efficiency were measured for 3 populations of the bivalve Scrobicularia plana (Da Costa) and related to temperature, body weight, reproductive cycle and particulate organic matter in the sediment. Quantitative estimates of the condition of $S$. plana were made at each site by 'scope for growth' measurements. Distinct population differences were observed, due in part to the different sediments and food levels at each site.
\end{abstract}

\section{INTRODUCTION}

Physiological differences between populations have been recorded for the marine bivalves Mytilus edulis L. (Bayne et al., 1977; Bayne and Widdows, 1978; Bayne and Worrall, 1980) and Mya arenaria L. (Gilfillan, 1975; Gilfillan et al., 1977). Existence and extent of such differences are of interest in considering the effects of different environmental conditions on the adaptability of individuals and of the overall physiological plasticity of a species. The main objective of this study was to investigate whether such differences exist in populations of the infaunal bivalve Scrobicularia plana (Da Costa) from different types of sediment.

The ecology of Scrobicularia plana has been studied by Hughes $(1969,1970)$ and Warwick and Price (1975). but little information exists on the physiological adaptations of the species. Many authors have observed, however, that populations of $S$. plana in estuaries of South West England show marked differences in tissue metal concentrations, and some of these populations also show differences in body size (Bryan, 1971; Boyden, 1977; Bryan and Hummerstone, 1977, 1978; Bryan and Uysal, 1978; Bryan et al., 1980). In this paper we compare the physiological attributes of individuals from 3 populations; in a companion paper (Worrall and Widdows, 1983) we report the results of reciprocal transplant experiments designed to examine the plasticity of these physiological adaptations.

\section{MATERIALS AND METHODS}

\section{Environmental factors}

Scrobicularia plana from 1 to $5 \mathrm{~cm}$ shell length were collected from the intertidal zone at low water spring tides in 3 estuaries in Cornwall, S. W. England - the Lynher, East Looe and Gannel (Fig. 1). Sampling was carried out between January 1977 and July 1979 at intervals of approximately $6 \mathrm{wk}$. The Lynher population was monitored for a year prior to physiological measurements being made on animals from E. Looe and Gannel and was considered the baseline or reference population.

Annual temperature fluctuations in the sediment at a depth of $10 \mathrm{~cm}$ varied from $5^{\circ} \mathrm{C}$ in winter to $18^{\circ} \mathrm{C}$ in summer. However, during August 1978 a sediment temperature of $21.5^{\circ} \mathrm{C}$ was measured at the sandy Gannel site (Fig. 2). Salinity at the Lynher site varied from $32 \% \mathrm{~S}$ in summer to a minimum of $8.5 \% \mathrm{~S}$ in winter, while interstitial salinities varied between $34.4 \%$ and $19.3 \% \mathrm{~S}$ (mean $27 \% \mathrm{~S}$ ). Mean interstitial salinities for E. Looe and Gannel were $20 \%$ and $24 \% \mathrm{~S}$ respectively. The sediment at the 3 sites varied between fine mud at the Lynher, coarse mud at $\mathrm{E}$. Looe, and fine sand at the Gannel.

\section{Particulate analysis}

Surface sediments from each of the 3 sites were analysed for protein, carbohydrate, lipid, and 

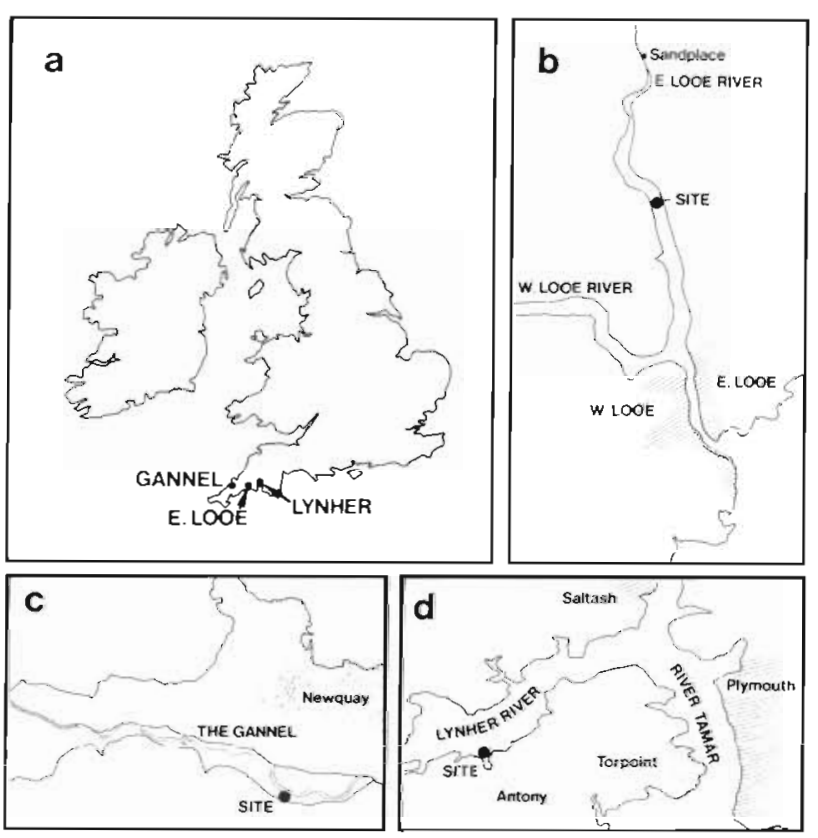

Fig. 1. General location of 3 sampling sites (a). Three estuaries (b, East Looe; c, Gannel; d, Lynher) showing sampling area from which Scrobicularia plana were collected

chlorophyll a to provide an estimate of food availability. A small quantity of surface sediment (20 to $50 \mathrm{mg}$ ) was filtered onto a washed, ashed and preweighed glass-fibre filter. Salts were washed out of the filter with isotonic ammonium formate. The filter was dried at $90^{\circ} \mathrm{C}$ and weighed. Carbohydrate, lipid and chlorophyll a concentrations were determined as described by Widdows et al. (1979). Protein was determined by the phenol-hypochlorite method of Grasshoff and Johannsen (1972).

Particulate organic matter (POM) in sediment at the 3 sites was determined by passing sediment through a $0.5 \mathrm{~mm}$ mesh sieve to remove animals and large shells. Shell fragments, Foraminifera and carbonate ores were dissolved by acidification with $1 \mathrm{~N}$ hydrochloric acid for $3 \mathrm{~h}$. The sediment was washed with distilled water onto an ashed and preweighed glassfibre filter, dried at $90^{\circ} \mathrm{C}$, and the loss of weight on ignition at $450^{\circ} \mathrm{C}$ was measured. Particle size analysis was carried out on the same sub-sieve fraction of sediment using a Coulter Counter model TA 11.

\section{Physiological measurements}

Bivalves were collected and maintained under controlled laboratory conditions (seasonal ambient temperature; seawater of $32 \% \mathrm{~S}$; fed at a concentration of $20 \times 10^{3}$ Phaeodactylum tricornutum cells $\mathrm{ml}^{-1}$ ). All physiological measurements were carried out on 18

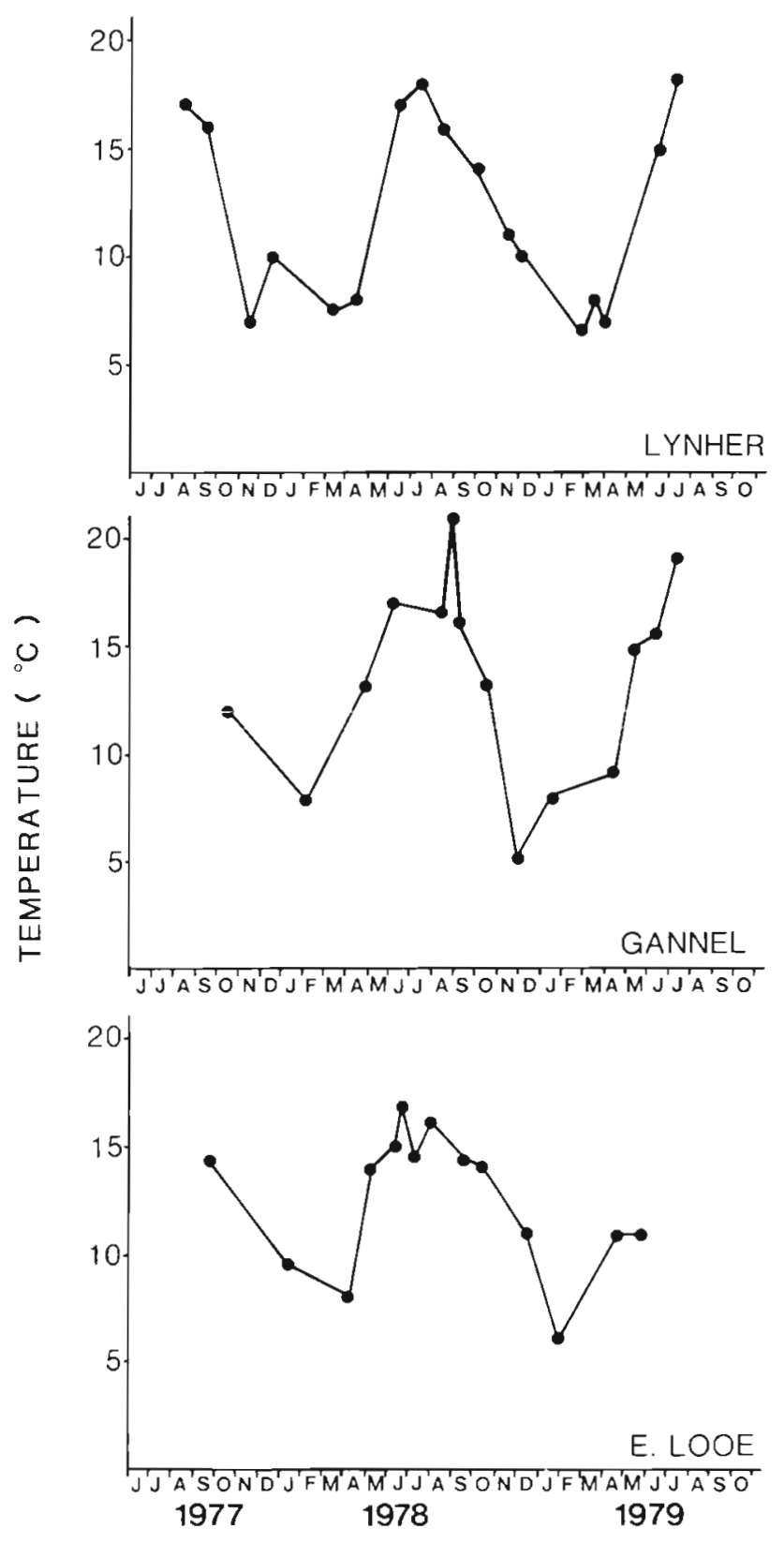

Fig. 2. Sediment temperature measurements taken at a depth of $10 \mathrm{~cm}$ at Lynher, Gannel and E. Looe sites

individuals between 18 and $96 \mathrm{~h}$ after the bivalves were introduced to the laboratory.

Rates of oxygen consumption $\left(\mathrm{VO}_{2} ; \mu \mathrm{O}_{2} \mathrm{~h}^{-1}\right)$ were measured using a Gilson differential respirometer (Gilson, 1963; Umbreit et al., 1964). Rates of ammonia excretion were determined by immersing Scrobicularia plana of different sizes in individual perspex containers with $100 \mathrm{ml}$ of filtered seawater for $7 \mathrm{~h}$ and comparing ammonia levels in control dishes without bivalves. The ammonia content of the water was measured by the method of Solorzano (1969) and the results were expressed as $\mu \mathrm{g} \mathrm{NH}_{4}-\mathrm{N}$ excreted $\mathrm{h}^{-1}$. 
Rates of deposit feeding and suspension feeding by Scrobicularia plana were determined. The ingestion rate ( $\mathrm{mg}$ sediment $\mathrm{h}^{-1}$ ) during deposit feeding was estimated as follows:

$$
\text { Ingestion rate }\left(\mathrm{mg} \mathrm{h}^{-1}\right)=\frac{\text { Egestion rate }\left(\mathrm{mg} \mathrm{h}^{-1}\right)}{1-\text { Absorption efficiency }}
$$

Egestion rate or faecal production rate was calculated (Hughes, 1969) from measurements of gut capacity (mg) and gut clearance time (h) at different temperatures. This estimate of ingestion rate did not represent a sufficiently routine or precise method of measuring and comparing the feeding activity of $S$. plana from 3 populations. Suspension feeding, or the clearance rate by $S$. plana was therefore used as a routine measure of feeding rate. Clearance rate $\left(\mathrm{ml} \mathrm{h}^{-1}\right)$ is defined as the volume of water cleared of all suspended particles $>2 \mu \mathrm{m}$ diameter in $1 \mathrm{~h}$. It was estimated in a static aerated system by measuring the exponential decline in the concentration of Phaeodactylum tricornutum using a Model ZB Coulter Counter. Clearance rate was calculated using the method described by Coughlan (1969).

The relationship between ingestion rate (IR) and clearance rate (CR), measured over a range of temperatures, is described by the following regression equation:

$$
\mathrm{IR}=0.299+26(\mathrm{CR}) ; \mathrm{n}=9 ; \mathrm{r}=0.84
$$

Food absorption efficiency of Phaeodactylum tricornutum cells cleared from suspension by Scrobicularia plana was measured by the ratio method of Conover (1966) and is defined as:

$$
U=\frac{(F-E)}{((1-E)(F))} \cdot 100
$$

where $F=$ ash-free dry mass: dry mass ratio in the ingested food; $E$ = same ratio in a sample of faeces. Faecal samples were obtained by feeding $S$. plana, $P$. tricornutum at a concentration of $20 \times 10^{3} \mathrm{cells} \mathrm{ml}^{-1}$ in a tank of flowing seawater. Both faeces and a sample of suspended food were collected on separated washed, ashed and preweighed glass-fibre filters which were then washed with isotonic ammonium formate to remove salts, dried at $90^{\circ} \mathrm{C}$, and the loss of weight on ignition at $450^{\circ} \mathrm{C}$ was estimated.

Length and dry tissue mass measurements were taken to determine the fit of the parameters to the allometric equation

$$
\mathrm{L}=\mathrm{d} \cdot \mathrm{W}^{\mathrm{r}}
$$

where $\mathrm{L}=$ length in $\mathrm{cm}_{i} \mathrm{~W}=$ dry tissue mass in $\mathrm{mg}$; $\mathrm{d}$ and $\mathrm{r}=$ parameters estimated by regression. Shell length and all physiological measurements $\left(\mathrm{VO}_{2}, \mathrm{CR}\right.$,
$\mathrm{VNH}_{4} \cdot \mathrm{N}$ ) were analysed by regression and covariance techniques following logarithmic (base 10) transformations. In each case the allometric model was applied:

$$
\mathrm{Y}=a \mathrm{X}^{b}
$$

where $\mathrm{Y}=$ physiological variable; $\mathrm{X}=$ dry flesh weight; $a$ and $b=$ intercept and gradient respectively. Results of regression analyses for each physiological variable were compared for the 3 populations. Where the null hypothesis of no statistically significant heterogeneity in gradient estimates was supported, a common gradient was calculated which was then used to recalculate new intercepts. Finally, the value of each physiological variable for a standard body size (100 mg) was calculated.

Rates of oxygen consumption, clearance rate and absorption efficiency have been converted into joule equivalents and integrated by means of the energy equation of Winberg (1960):

$$
\mathrm{C}=\mathrm{P}+\mathrm{R}+\mathrm{U}+\mathrm{F}
$$

where $\mathrm{C}=$ ingested ration; $\mathrm{P}=$ production of both somatic growth and gametes ('scope for growth'); $\mathrm{R}=$ respiratory heat loss; $\mathrm{U}=$ energy lost as urine; $\mathrm{F}=$ energy lost as faeces.

The absorbed ration (A) can be expressed as the product of food consumption (C) and absorption efficiency. Scope for growth $(P)$ can then be expressed as a function of $A, R$, and $U$ (Warren and Davies, 1967):

$$
\mathrm{P}=\mathrm{A}-(\mathrm{R}+\mathrm{U})
$$

The calculation of scope for growth is as follows: $\mathrm{C}\left(\mathrm{Jh}^{-1}\right)=$ ingestion rate $\left(\mathrm{mg} \mathrm{h}^{-1}\right) \times$ food concentration (non-refractory organic matter, $\mathrm{J} \mathrm{mg}^{-1}$; Table 1);

$\mathrm{A}\left(\mathrm{Jh}^{-1}\right)=\mathrm{C} \times$ absorption efficiency;

$\mathrm{R}\left(\mathrm{Jh}^{-1}\right)=$ respiration rate $\left(\mathrm{ml} \mathrm{O} \mathrm{O}^{-1}\right) \times 20.33 \mathrm{~J}$;

$\mathrm{U}\left(\mathrm{Jh}^{-1}\right)=$ ammonia nitrogen excretion rate $(\mathrm{mg}$ $\left.\mathrm{NH}_{4} \mathrm{~N} \mathrm{~h}^{-1}\right) \times 24.9 \mathrm{~J}$; scope for growth $\left(\mathrm{Jh}^{-1}\right)=\mathrm{A}-(\mathrm{R}$ $+\mathrm{U})$.

The oxygen:nitrogen ratio $(\mathrm{O}: \mathrm{N})$ was calculated from oxygen consumption and ammonia excretion measurements in atomic equivalents (Corner and Cowey, 1968; Bayne, 1976).

Areas of the gills of Scrobicularia plana were measured microscopically, with an eyepiece graticule containing a calibrated grid system, after 1 valve was removed, the mantle cavity flooded with seawater and the gill floated off the visceral mass. The square root of the gill area (Hughes, 1969) was then analysed by regression against dry tissue weight.

Rates of oxygen consumption $\left(\mathrm{VO}_{2}\right)$ by Scrobicularia plana were also measured in response to declining oxygen tension $\left(\mathrm{pO}_{2}\right)$. Seawater was passed through a gas-liquid exchange column bubbled with nitrogen to 
reduce oxygen tension. Oxygen-depleted seawater passed via a temperature equilibration coil and flow meter to an experimental chamber (volume $140 \mathrm{ml}$ ) containing a bivalve and oxygen electrode which was connected to a Radiometer Gas Analyser and chart recorder. For a full experimental procedure see Bayne $(1971 \mathrm{a}, \mathrm{b})$.

Table 1. Estimation of 'non-refractory organic matter' ( $\mathrm{J} \mathrm{mg}^{-1}$ ) in the sediment based on the sum of carbohydrate (C), protein (P) and lipid (L). Carbohydrate $=17.15 \mathrm{~J} \mathrm{mg}^{-1}$, Protein $=23.64 \mathrm{~J} \mathrm{mg}^{-1}$ and Lipid $=39.54 \mathrm{~J} \mathrm{mg}^{-1}$

\begin{tabular}{|lccc|}
\hline \multicolumn{1}{c}{ Date } & $\begin{array}{c}\text { Lynher } \\
\Sigma(\text { C.P.L. })\end{array}$ & $\begin{array}{c}\text { E. Looe } \\
\text { (C.P.L.) }\end{array}$ & $\begin{array}{c}\text { Gannel } \\
\Sigma(\text { C.P.L. })\end{array}$ \\
\hline Sep 1977 & - & 1.421 & - \\
Oct & - & - & 0.441 \\
Dec & 0.865 & - & - \\
Jan 1978 & - & 0.720 & - \\
Mar & 0.626 & - & 0.473 \\
Apr & 0.473 & 0.335 & 0.322 \\
May & - & 0.351 & - \\
Jun & 0.564 & 0.467 & 0.279 \\
Jul & - & 0.453 & - \\
Aug & 0.587 & - & 0.292 \\
Sep & - & 0.813 & - \\
Oct & 0.668 & - & 0.266 \\
Nov & 0.463 & - & 0.305 \\
Dec & - & 0.258 & - \\
Jan 1979 & - & - & 0.385 \\
Feb & 0.546 & 0.355 & - \\
Mar & 0.658 & 0.516 & - \\
Apr & - & 0.505 & 0.364 \\
May & - & 0.874 & 0.649 \\
Jun & 1.301 & - & 0.730 \\
Jul & - & - & 0.799 \\
Mean \pm S.E. & $0.675 \pm .078$ & $0.589 \pm .094$ & $0.442 \pm .053$ \\
& & & \\
\hline
\end{tabular}

Clearance rate were also measured in response to declining $\mathrm{pO}_{2}$ using apparatus described above for $\mathrm{VO}_{2}$ measurements. Bivalves were left to equilibrate for $1 \mathrm{~h}$ in flow-through experimental chambers with seawater at full oxygen saturation and each chamber was then sealed with 2 silicone rubber stoppers. A $5 \mathrm{ml}$ syringe was used to inject Phaeodactylum tricornutum cells into each experimental chamber through 1 of the stoppers and water samples were removed in a similar manner. A syringe, forming a displacement reservoir, was connected to each chamber via a needle which passed through the second stopper.

Gametogenic condition of Scrobicularia plana was assessed on individuals of 3.5 to $4.5 \mathrm{~cm}$ shell length. Whole individuals were removed from their shells and fixed in Baker's Formal Calcium (Bancroft, 1967) for $24 \mathrm{~h}$ at $4{ }^{\circ} \mathrm{C}$ followed by dehydration in an ascending alcohol series. Tissue was embedded in wax and $5 \mu \mathrm{m}$ sections cut and stained by the Papanicolaou method (Culling, 1963). The gametogenic condition of S. plana gonads were staged from 0 to 3 (spawned $=0$, resting 1 , developing $=2$, and ripe $=3$ ).

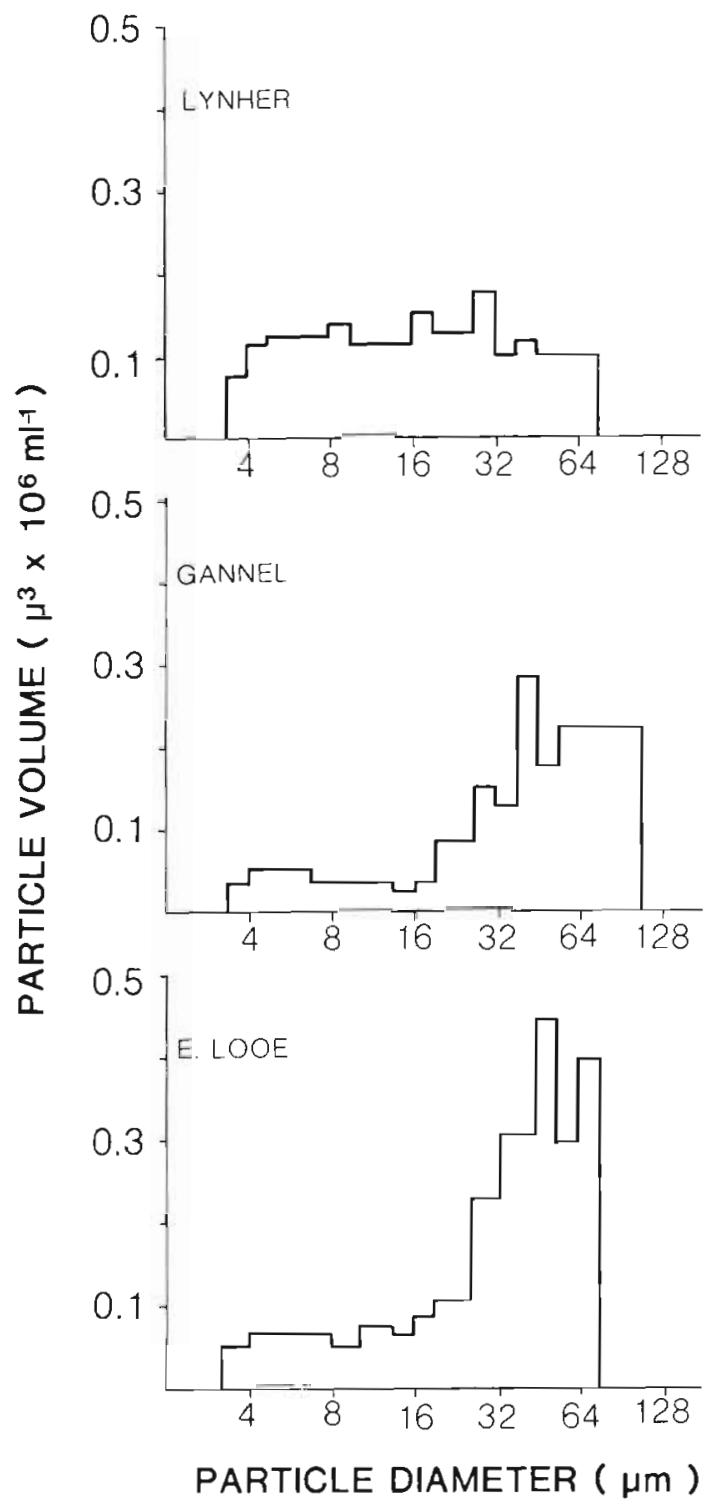

Fig. 3. Histogram plot of sediment particle volume against sediment particle diameter (spherical equivalent) at Lynher,

Gannel and E. Looe sites

\section{RESULTS}

\section{Composition of sediment}

The particle size distribution (Fig. 3) showed that the Lynher sediment was a fine mud with a uniform size distribution, whereas the $E$. Looe sediment was a coarse mud and the Gannel was a fine sand with the largest particle diameter of the 3 sites. Gannel sediment also contained many Foraminifera shells and a 
high level of calcareous material. A cumulative curve of particle volume against diameter was used to determine the median diameter for sediments collected from the 3 sites (Lynher $23 \mu \mathrm{m}$; E. Looe $47 \mu \mathrm{m}$; Gannel $50 \mu \mathrm{m})$. The symmetry of the spread of particles on either side of the median diameter, the phi quartile skewness (Skq Ø), was calculated (Buchanan and Kain, 1971). A positive value for the asymmetry indicates that the mean of the quartiles lies to the right of the median diameter, whereas a negative value indicates a skewness to the left of the median (Lynher Skq $\varnothing=-0.040$; E. Looe Skq $\varnothing=+0.035$; Gannel Skq $\varnothing$ $=+0.160$ ).

The proportion of organic matter in the surface sediments varied seasonally from low values in winter to higher values in summer, with a range of 6.3 to $9.1 \%$ at Lynher, 2.1 to $3.9 \%$ at E. Looe and 3.8 to $4.4 \%$ at Gannel. The organic content of the sandy Gannel sediment may be an overestimation due to the presence of a large number of anthracite dust particles which were burnt off in the ashing process with the organics ( $E$. Hamilton pers. comm.). The food value of surface sediments was assessed as carbohydrate, protein, lipid and chlorophyll a concentrations at each site (Fig. 4). Lynher and E. Looe showed a marked peak in lipid and chlorophyll a concentration in late summer/autumn but the Gannel sediment showed relatively little seasonal fluctuation. Surface sediment food values were lowest at the Gannel (Table 1).

\section{Reproductive condition}

The gonadal tissue of Scrobicularia plana ramifies throughout the foot and digestive gland making quantitative stereological analysis (Lowe et al., 1982) difficult. In all 3 populations follicles were empty between October and February except for a peripheral layer of primary germ cells. Gametogenesis commenced between March and May and proceeded in the normal developmental series.

Spawning occurred between July and September at sediment temperatures of 15 to $17^{\circ} \mathrm{C}$. In 1978 gamete development (Stage 2) in Scrobicularia plana at the Lynher site was initiated in April; at the E. Looe site it had been initiated by April; in the Gannel individuals development started later during May/June. Gannel bivalves had spawned out by July/August, after a much shorter period of gametogenesis. Although ripe gametes (Stage 3) were not observed between June and August (Fig. 5) there was no evidence to suggest that the Gannel bivalves resorbed their gametes and did not spawn. E. Looe and Lynher bivalves spawned later in September and October, respectively (Fig. 5).

\section{Length-weight analysis}

Tissue weight changes of Scrobicularia plana at a shell length of $3 \mathrm{~cm}$ are plotted in Fig. 6. Lynher and E. Looe bivalves showed marked seasonal changes in
Fig. 4. (A) Seasonal changes in percent carbohydrate in surface sediments. (B) Seasonal changes in percent protein in surface sediments. (C) Seasonal changes in percent lipid in surface sediments; dotted line denotes no data available for July 1978. (D) Seasonal variations in chlorophyll a content of surface sediments. The

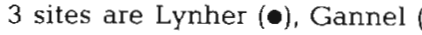
and E. Looe (A)
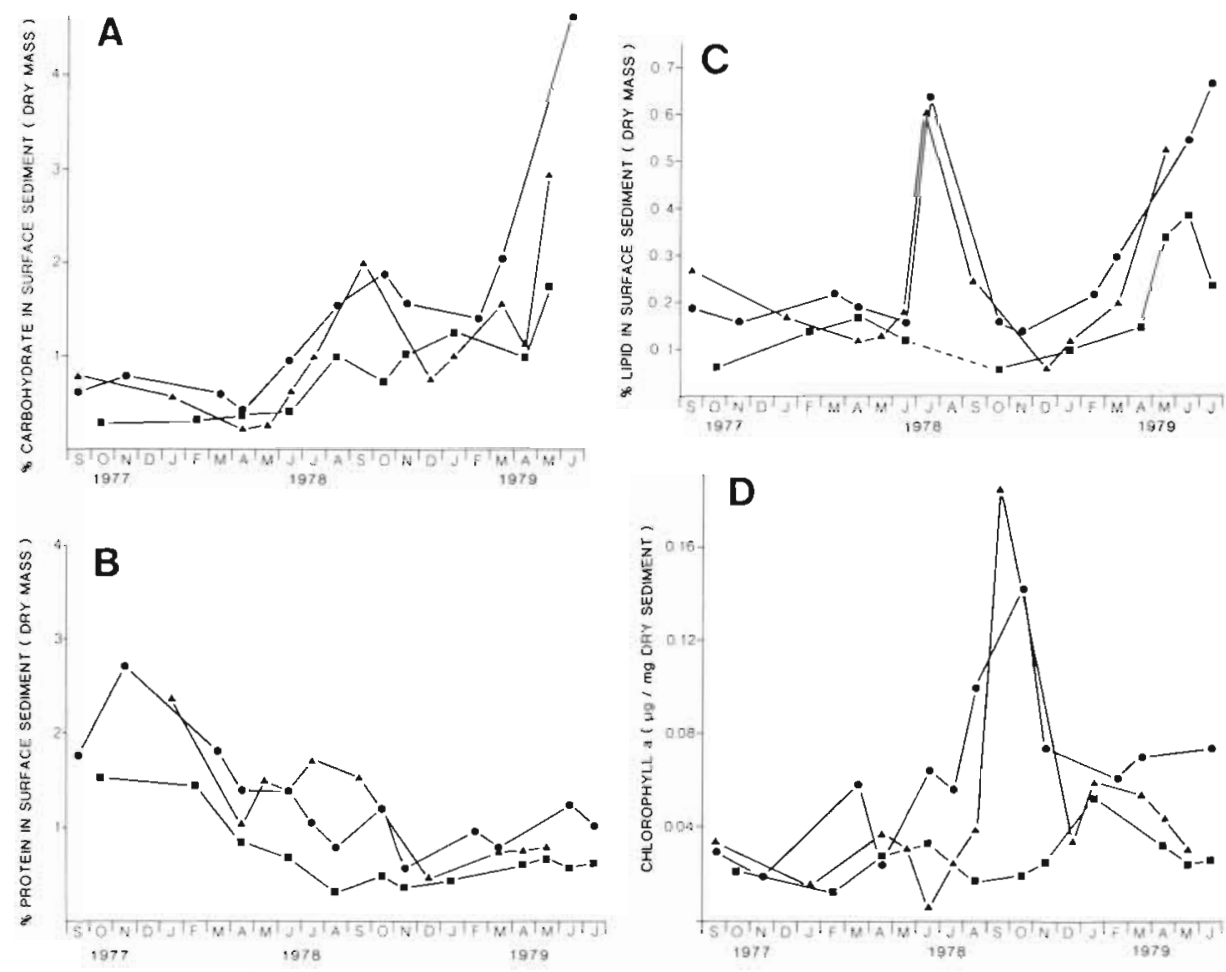


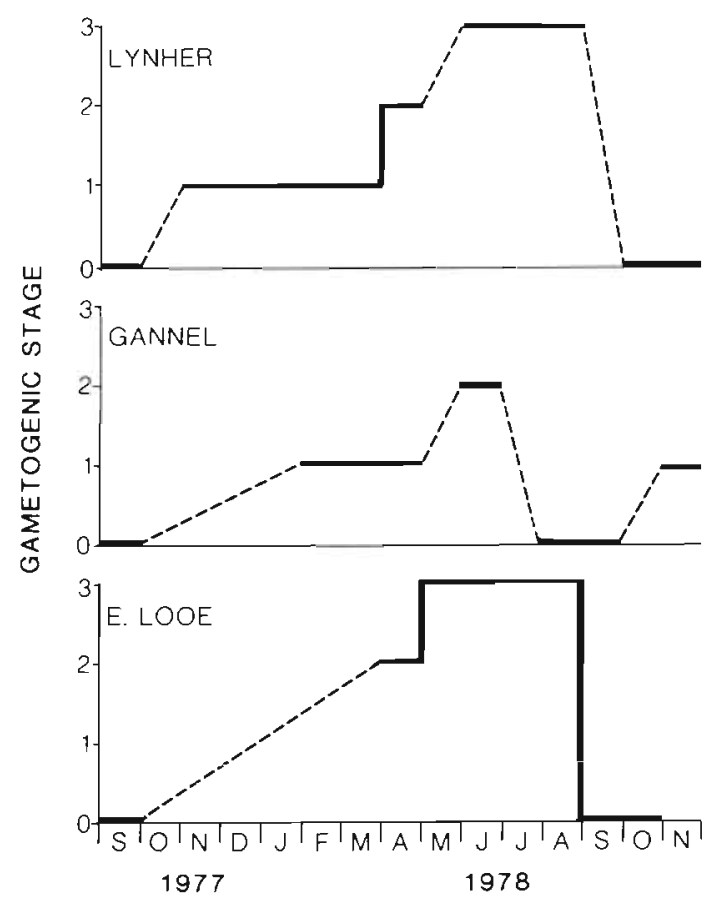

Fig. 5. Scrobicularia plana. Gametogenic staging of individuals from Lynher, Gannel and E. Looe sites. Spawned (0), resting (1), developing (2) and ripe (3). No sample indicated by dotted line

body weight with a rapid increase in tissue dry weight in spring and summer. Gannel bivalves had a significantly lower weight per unit shell length and showed less seasonal variation.

\section{Rates of oxygen consumption}

The relationship between rate of oxygen consumption $\left(\mathrm{VO}_{2} ; \mu \mathrm{O}_{2} \mathrm{~h}^{-1}\right)$ and dry tissue weight (mg) of Scrobicularia plana was analysed by least squares regression. Covariance analysis of the data for the Lynher and Gannel individuals showed that the gradients $b$ in the allometric equation were not significantly heterogeneous over time $(\mathrm{P}>0.05)$. Data were reanalysed using the common gradients (Lynher $b=$ 0.76 ; Gannel $b=0.81$ ) to calculate the rate of oxygen consumption by a standard sized individual of $100 \mathrm{mg}$ dry weight. Gradients at E. Looe were significantly heterogeneous over time $(\mathrm{P}<0.01)$. The rates of oxygen consumption by $S$. plana (100 $\mathrm{mg}$ dry weight) from the Lynher, E. Looe and Gannel are plotted in Fig. $7 \mathrm{~A}$. Rates of $\mathrm{VO}_{2}$ were maximal in summer and minimal in winter for the 3 populations.

\section{Clearance rates}

The relationship between clearance rate $\left(\mathrm{CR}_{i} \mathrm{ml} \mathrm{h}^{-1}\right)$ and dry tissue weight (mg) of Scrobicularia plana was

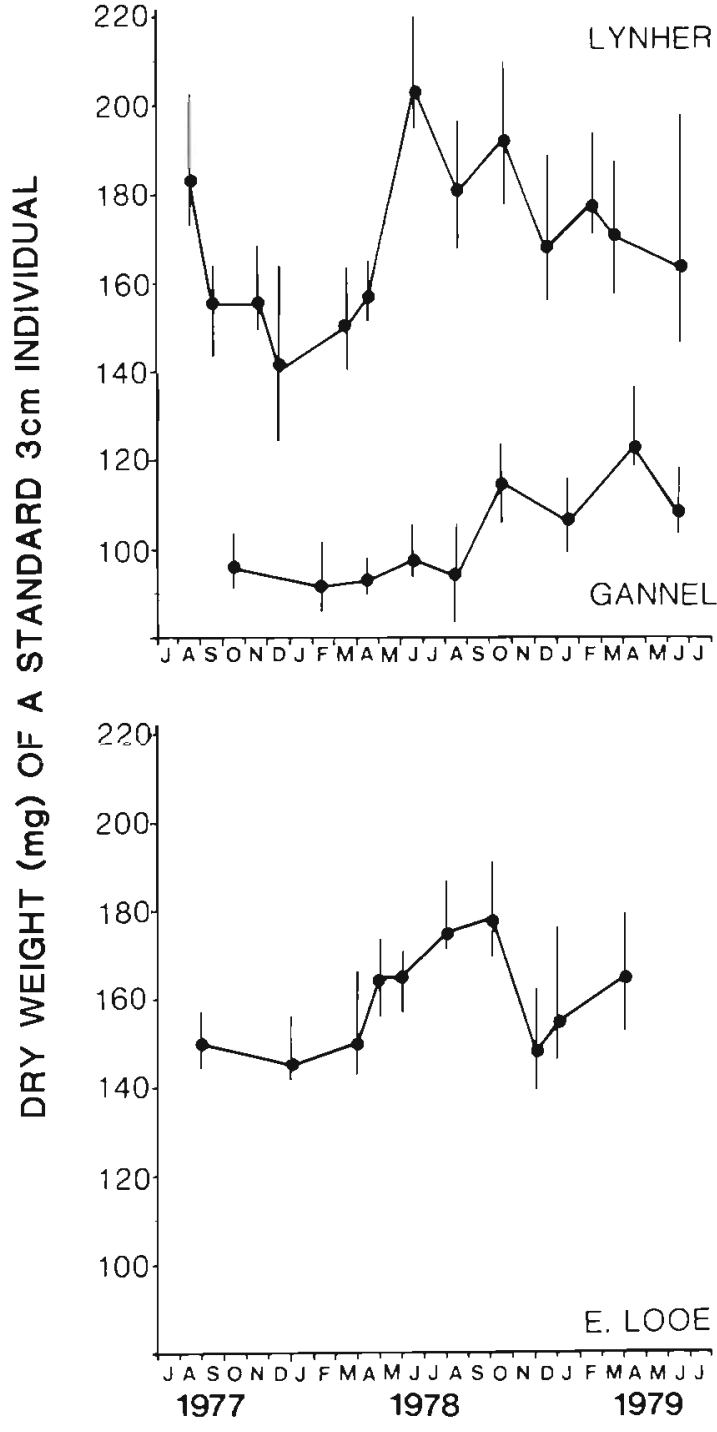

Fig. 6. Scrobicularia plana. Seasonal changes in dry flesh weight (mg) of a standard ( $3 \mathrm{~cm}$ shell length) individual from Lynher, Gannel and E. Looe populations (from monthly length/weight regression analyses). Mean $\pm 95 \%$ confidence limits

also analysed by least squares regression. Covariance analysis showed that the gradients for the Lynher and Gannel populations were not significantly heterogeneous ( $P>0.05$ ) and a common gradient (Lynher $b=$ 0.78 ; Gannel $b=0.79$ ) was then used to calculate the clearance rates for an individual of standard body size (100 mg dry weight). At E. Looe, gradients were significantly heterogeneous over time $(P<0.001)$. Clearance rates of $S$. plana (100 $\mathrm{mg}$ dry weight) from the 3 sites are plotted in Fig. 7 B. All populations had minimum rates during winter, and both Gannel and Lynher individuals had maximal rates in summer between July and October, but E. Looe individuals did not show an obvious summer maximum. Throughout 
Fig. 7. Scrobicularia plana. (A) Seasonal changes in rates of oxygen consumption $\left(\mathrm{VO}_{2} ; \mu \mathrm{l} \mathrm{O} \mathrm{h}^{-1}\right)$ by individuals of $100 \mathrm{mg}$ dry flesh weight from Lynher, Gannel and E. Looe sites. Mean $\pm 95 \%$ confidence limits. (B) Seasonal changes in clearance rates $(C R$; $\mathrm{ml}$ water $\mathrm{h}^{-1}$ ) by individuals of $100 \mathrm{mg}$ dry flesh weight from Lynher, Gannel and E. Looe sites. Mean $\pm 95 \%$ confidence limits

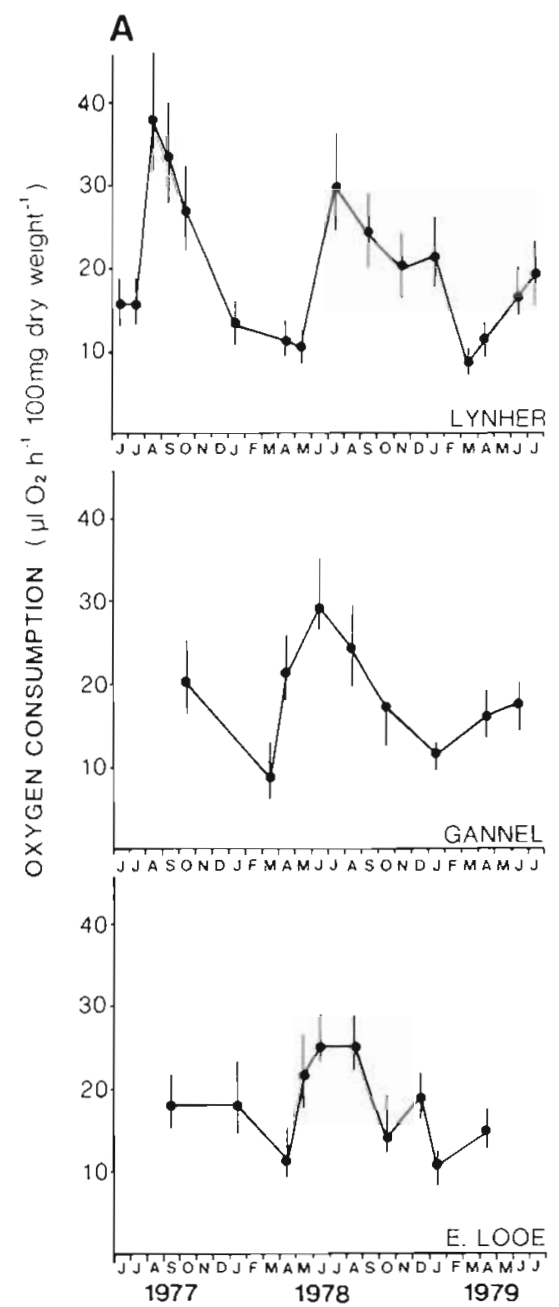

most of the year, $S$. plana from the Gannel had higher clearance rates than the Lynher and E. Looe individuals.

\section{Ammonia excretion}

Covariance analysis of the relationship between ammonia excretion $\left(\mathrm{VNH}_{4} \cdot \mathrm{N}_{i} \mu \mathrm{g} \mathrm{NH}_{4} \cdot \mathrm{Nh}^{-1}\right)$ and dry tissue weight for the Lynher individuals showed that the gradients were not significantly heterogeneous over time $(\mathrm{P}>0.05)$ and the data were reanalysed using a common gradient $(b=0.62)$ to calculate the excretion rates for a standard sized individual (100 mg dry weight). Gradients at E. Looe ( $b=0.73$ to 0.95 ) and Gannel ( $b=0.31$ to 0.87 ) were significantly heterogeneous at $\mathrm{P}<0.001$ and $\mathrm{P}<0.01$, respectively. The rate of ammonia excretion by Scrobicularia plana varied seasonally and between populations (Fig. 8 A). In all 3 populations ammonia excretion increased rapidly after June during the period of elevated rates of oxygen consumption, gamete maturation and higher temperatures.
B
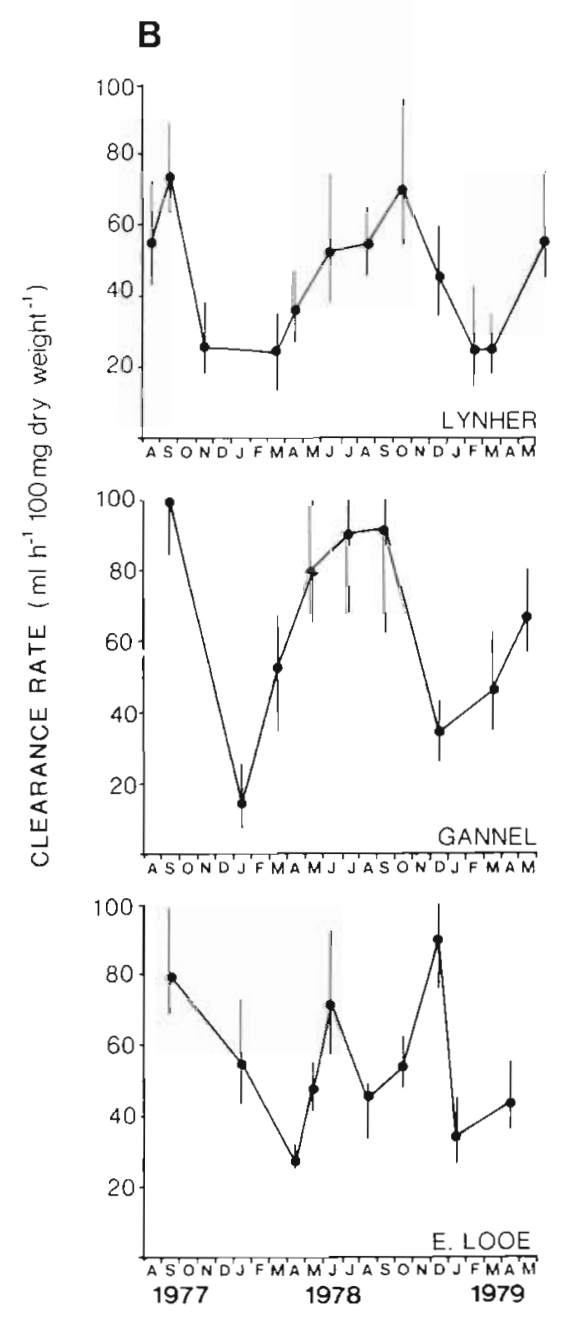

\section{Oxygen: Nitrogen ratio}

The ratio between rates of oxygen consumption and nitrogen excretion indicates the proportion of protein relative to carbohydrate and lipid that is catabolized for energy metabolism. A high rate of protein relative to lipid and carbohydrate catabolism results in a low $O: N$ ratio. The $O: N$ ratios for Scrobicularia plana from the 3 sites were highest in spring at the time of phytoplankton bloom, but then declined during the spawning period (August-September) and remained low throughout the winter (Fig. 8 B).

\section{Convection requirement}

The convection requirement represents the volume of water cleared per $\mathrm{ml}$ of oxygen consumed. This relationship is significant for energy balance of the individual since the clearance rate is a measure of the intensity of feeding activity and the rate of oxygen consumption provides an indication of the food 
A

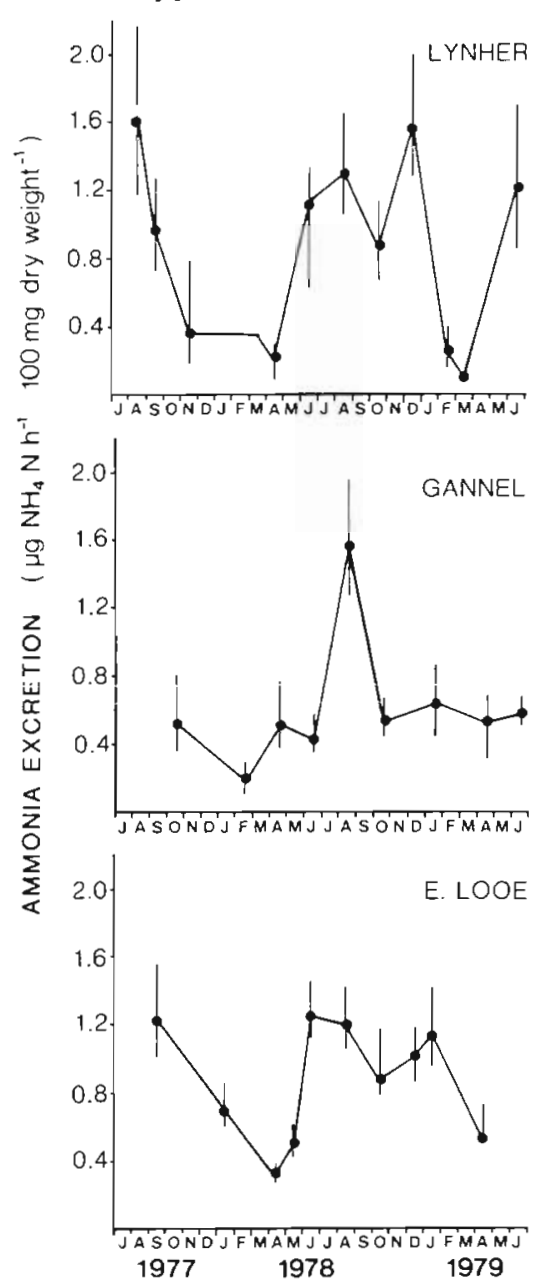

B
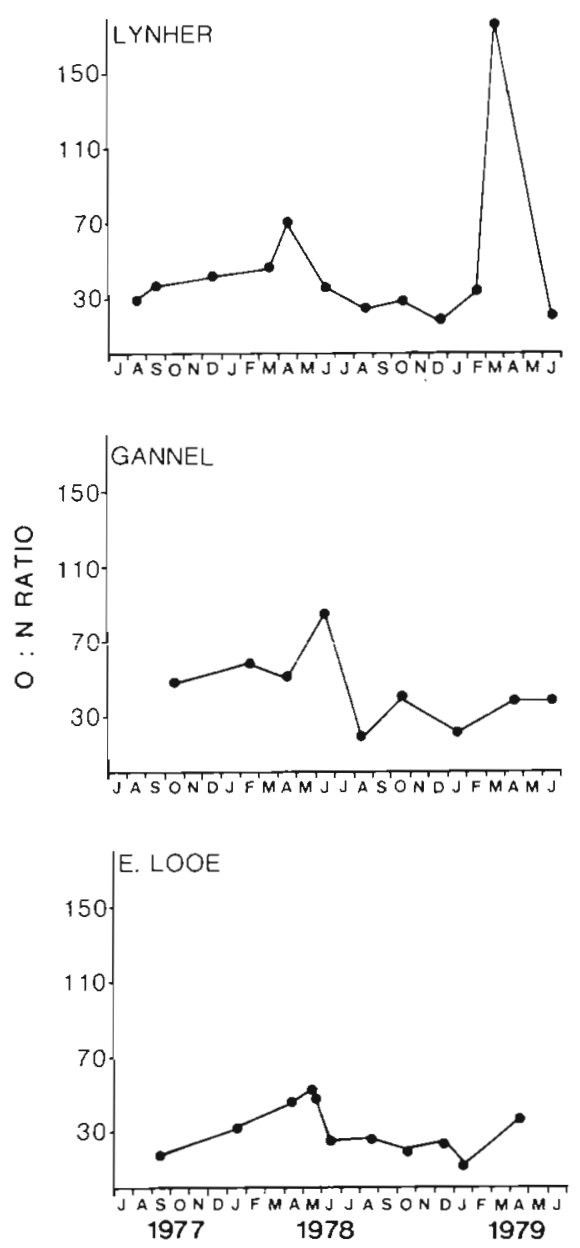

Fig. 8. Scrobicularia plana. Seasonal changes in rates of ammonia-nitrogen excretion $\left(\mathrm{VNH}_{4} \cdot \mathrm{N}: \mu \mathrm{g} \mathrm{NH}_{4} \cdot \mathrm{N} \mathrm{h}^{-1}\right)$ by individuals of $100 \mathrm{mg}$ dry flesh weight from Lynher, Gannel and E. Looe sites. Mean $\pm 95 \%$ confidence limits. (B) Seasonal changes in oxygen:nitrogen ratio of individuals of $100 \mathrm{mg}$ dry flesh weight from Lynher, Gannel and E. Looe sites requirement. The values for the convection requirement of Scrobicularia plana from the 3 populations (mean \pm S.E.: Lynher $2.68 \pm 0.30$; E. Looe $3.06 \pm 0.34 ;$ Gannel 4.20 \pm 0.45 ) showed that there was no significant difference between Lynher and $E$. Looe individuals. However, the convection requirement of the Gannel population was significantly higher $(\mathrm{P}<0.05)$ than the other 2 populations, suggesting that the Gannel individuals were more efficient at balancing their feeding against their food requirements.

\section{Gill area}

In Fig. 9 square roots of gill areas are plotted against dry tissue weight on logarithmic (base 10) scales. There was a linear relationship in all cases and covariance analysis of paired populations (Lynher vs. E. Looe, E. Looe vs. Gannel, Lynher vs. Gannel) showed a significant difference between the gill area per unit body weight for each pair ( $\mathrm{P}<0.001$ ). Gannel bivalves had significantly larger gill areas per unit body weight (Gannel > E. Looe > Lynher). The regression equations for the 3 populations were:

Lynher, $\mathrm{Y}=-0.357+0.476(\mathrm{X}), \quad(\mathrm{n}=26, \mathrm{r}=0.98)$; E. Looe, $Y=-0.509+0.371(X), \quad(n=25, r=0.96)$; Gannel, $\mathrm{Y}=-0.201+0.050(\mathrm{X}), \quad(\mathrm{n}=30, \mathrm{r}=0.98)$, where $\mathrm{Y}=\log _{10}$ square root gill area $\left(\mathrm{mm}^{2}\right)$ and $\mathrm{X}=$ $\log _{10}$ dry flesh weight (mg).

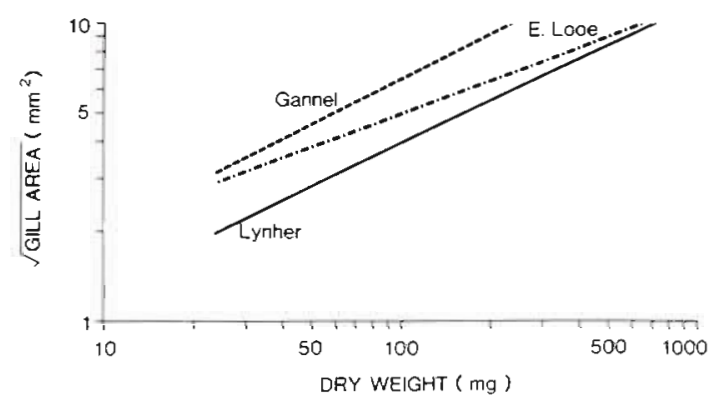

Fig. 9. Scrobicularia plana. Relationship between square root of gill area and dry flesh weight plotted on logarithmic (base 10) scale of individuals from Lynher, Gannel and E. Looe sites 


\section{Oxygen consumption and clearance rates in declining oxygen tension}

Graphs of $\log _{10} \mathrm{VO}_{2}$ against $\log _{10} \mathrm{pO}_{2}$ were fitted by least squares and the mean slope $(\beta)$ for 12 individuals from each population was estimated: Lynher $\beta=0.80$; E. Looe $\beta=0.72$; Gannel $\beta=0.47$ (Fig. $10 \mathrm{~A}$ ). An
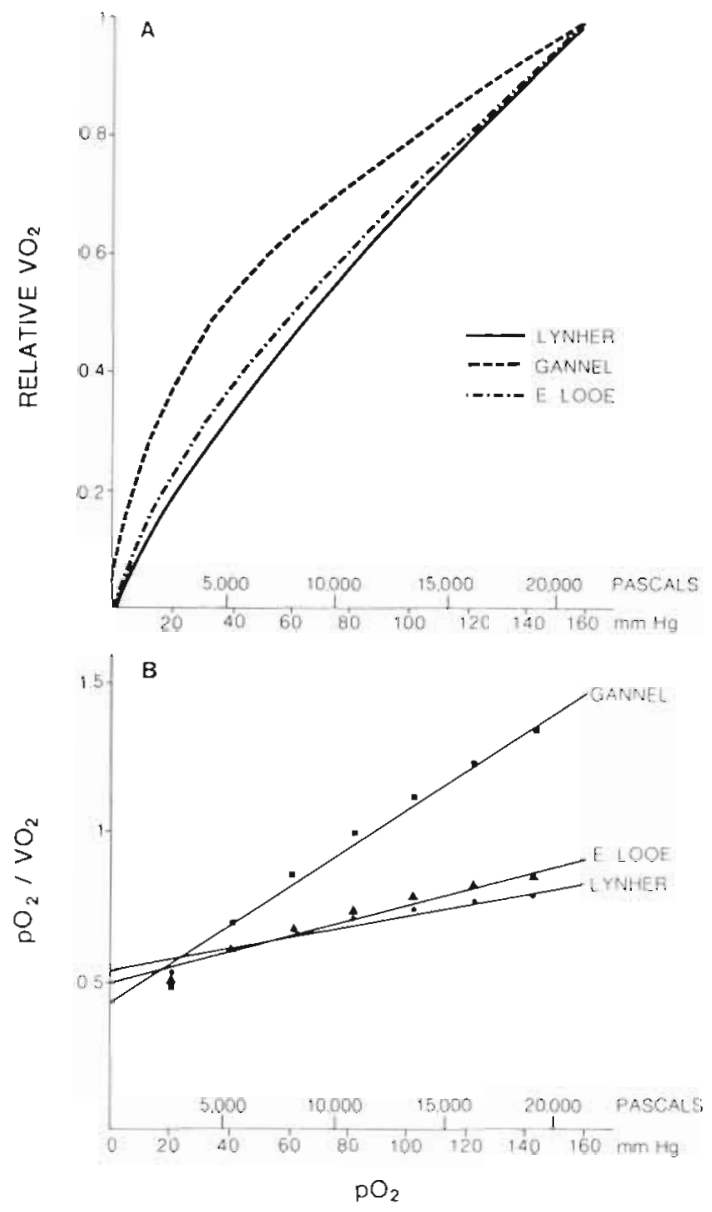

Fig. 10. Sctobicularia plana. (A) Plot of Relative $\mathrm{VO}_{2}$ as a function of $\mathrm{pO}_{2}$ ( $\left.\mathrm{mmHg} / \mathrm{Pascals}\right)$. The 3 curves are standardized to pass through the point Relative $\mathrm{VO}_{2}=1$ at $\mathrm{pO}_{2}=160$ $\mathrm{mmHg}$. The 3 sites are Lynher $(-, \beta=0.80)$, E. Looe $(\cdot-\cdot-\cdot-$, $\beta=0.72$ ), and Gannel $(---, \beta=0.47)$. (B) Regression lines for $\mathrm{pO}_{2} / \mathrm{VO}_{2}$ as a function of $\mathrm{pO}_{2}(\mathrm{mmHg} /$ Pascals) for Lynher $(\bullet)$ E. Looe (^) and Gannel ( $\bullet$ ) populations. The intercepts $\left(K_{1}\right)$ and the slopes $\left(K_{2}\right)$ of the lines are: Lynher $\left(K_{1}=0.5329\right.$, $\left.\mathrm{K}_{2}=0.0019\right)$; E. Looe $\left(K_{1}=0.4850, K_{2}=0.0027\right)$; Gannel $\left(K_{1}\right.$ $\left.=0.4181, \mathrm{~K}_{2}=0.0067\right)$

F-test established that the Gannel population differed significantly $(P<0.01$ ) from Lynher and E. Looe populations.

A standard approach to comparing the degree of oxy-conformity or oxygen-regulation of the curves relating $\mathrm{VO}_{2}$ to $\mathrm{pO}_{2}$ is that proposed by Tang (1933); this approach has been used by Bayne $(1971 a, b)$ and
Taylor and Brand (1975). Following the above transformation the data are presented in linear form with the ratio of $\mathrm{pO}_{2} / \mathrm{VO}_{2}$ plotted as a function of $\mathrm{pO}_{2}$ (Fig. $10 \mathrm{~B})$. The intercept $\left(\mathrm{K}_{1}\right)$ and slope $\left(\mathrm{K}_{2}\right)$ can then be used to compare the degree of regulation or conformity in terms of the ratio $K_{1} / K_{2}$. The results were: Lynher 281; E. Looe 179; Gannel 63. A high ratio indicates the dependent curve of an oxy-conformer and a low ratio indicates a curve of $\mathrm{VO}_{2}$ which is regulated independently of external $\mathrm{pO}_{2}$. Gannel bivalves were able to maintain or 'regulate' their $\mathrm{VO}_{2}$ at reduced $\mathrm{pO}_{2}$ to a greater degree than either Lynher or E. Looe individuals.

Clearance rates, weight corrected to a standard $100 \mathrm{mg}$ individual, were also calculated at declining $\mathrm{pO}_{2}$. At $50 \mathrm{~mm} \mathrm{Hg}$ the clearance rates of individuals from Lynher were $40 \pm 3 \mathrm{ml} \mathrm{h} \mathrm{h}^{-1} ; \mathrm{E}$. Looe, $73 \pm 14 \mathrm{ml} \mathrm{h}^{-1}$; Gannel, $122 \pm 10 \mathrm{ml} \mathrm{h}^{-1}$.

\section{Scope for growth}

The scope for growth of a standard $100 \mathrm{mg}$ individual from the 3 Scrobicularia plana populations was calculated by subtracting respired and excreted energy losses from the energy content of the absorbed portion of the ingested ration (Tables 2 to 4 ). Because the ingestion rate of $S$. plana, resulting from both deposit and suspension feeding, could not be determined directly by a simple routine method, the clearance rate was used as an estimate of feeding activity in the calculation of scope for growth (see Materials and Methods') for the relationship between ingestion rate and clearance rate). The ingested ration was calculated from the ingestion rate and the sum of carbohydrate, protein and lipid in the sediment (non-refrac-

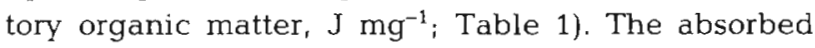
ration ( $\mathrm{A}$ in the scope for growth equation) was calculated using the absorption efficiency.

Cammen (1980) established a relationship between ingestion rate of deposit feeders and body size for a wide range of species. However, the ingestion rates of the bivalves Scrobicularia plana (Hughes, 1969, 1970) and Portlandia arctica (Bubnova, 1972) were found to be significantly lower than that predicted by the relationship for the other deposit feeders. Our ingestion rates for $S$. plana from the 3 populations are in agreement with Hughes $(1969,1970)$ and may be an underestimation. In calculating gut clearance time, which was the time required for sediment to pass completely through the gut, there may have been a disturbance effect on transferring bivalves from natural sediment to ashed sediment and then back to natural sediment, during which time the progress of the marker (the ashed sediment) was followed through the gut. No 
Table 2. Scrobicularia plana. Calculation of scope for growth in the Lynher population. See 'Material and Methods' for details of calculation. Non-refractory organic matter (Table 1); $\mathrm{VO}_{2}=$ oxygen consumption; $\mathrm{VNH}_{4} \mathrm{~N}=$ ammonia-nitrogen excretion. Values of $20.33 \mathrm{~J} \mathrm{ml}^{-1}$ of oxygen consumed and $24.9 \mathrm{~J} \mathrm{mg}^{-1}$ ammonia-nitrogen excreted and used to convert $\mathrm{VO}_{2}$ and $\mathrm{VNH}_{4} \mathrm{~N}$ respectively into energy equivalents

\begin{tabular}{|c|c|c|c|c|c|c|c|c|c|c|c|}
\hline \multirow[t]{2}{*}{ Date } & \multirow{2}{*}{$\begin{array}{l}\text { Ingestion } \\
\text { rate } \\
\left(\mathrm{mg} \mathrm{h}^{-1}\right)\end{array}$} & \multirow{2}{*}{$\begin{array}{l}\text { Non- } \\
\text { refractory } \\
\text { organic } \\
\text { matter } \\
\left(\mathrm{J} \mathrm{mg}^{-1}\right)\end{array}$} & \multirow{2}{*}{$\begin{array}{l}\text { Ingested } \\
\text { ration } \\
\left(\mathrm{J} \mathrm{h}^{-1}\right)\end{array}$} & \multirow{2}{*}{$\begin{array}{l}\text { Absorp- } \\
\text { tion } \\
\text { efficiency }\end{array}$} & \multirow{2}{*}{$\begin{array}{l}\text { Absorbed } \\
\text { ration } \\
\left(\mathrm{J} \mathrm{h}^{-1}\right)\end{array}$} & \multirow{2}{*}{$\begin{array}{c}\mathrm{VO}_{2} \\
\left(\mathrm{ml} \mathrm{h}^{-1}\right)\end{array}$} & \multirow{2}{*}{$\begin{array}{c}\mathrm{VO}_{2} \\
\left(\mathrm{~J} \mathrm{~h}^{-1}\right)\end{array}$} & \multirow{2}{*}{$\begin{array}{c}\mathrm{VNH}_{4} \cdot \mathrm{N} \\
\left(\mu \mathrm{g} \mathrm{h}^{-1}\right)\end{array}$} & \multirow{2}{*}{$\begin{array}{c}\mathrm{VNH}_{4} \cdot \mathrm{N} \\
\left(\mathrm{J} \mathrm{h}^{-1}\right)\end{array}$} & \multicolumn{2}{|c|}{$\begin{array}{l}\text { Scope for } \\
\text { growth }\end{array}$} \\
\hline & & & & & & & & & & $\left(\mathrm{J} \mathrm{h}^{-1}\right)$ & $\left(\mathrm{J} \mathrm{d}^{-1}\right)$ \\
\hline \multicolumn{12}{|l|}{$\begin{array}{l}\text { Native } \\
\text { animals }\end{array}$} \\
\hline Dec 77 & 0.975 & 0.865 & 0.843 & 0.38 & 0.320 & 0.012 & 0.24 & 0.36 & 0.009 & +0.071 & +1.72 \\
\hline Mar 78 & 0.923 & 0.626 & 0.578 & 0.25 & 0.145 & 0.013 & 0.26 & 0.35 & 0.009 & -0.124 & -2.98 \\
\hline Apr 78 & 1.235 & 0.473 & 0.584 & 0.30 & 0.175 & 0.011 & 0.23 & 0.21 & 0.005 & -0.060 & -1.43 \\
\hline Jun 78 & 1.651 & 0.564 & 0.931 & 0.55 & 0.512 & 0.031 & 0.63 & 1.12 & 0.028 & -0.146 & -3.50 \\
\hline Oct 78 & 2.119 & 0.668 & 1.415 & 0.42 & 0.595 & 0.019 & 0.39 & 0.86 & 0.021 & +0.184 & +4.42 \\
\hline Feb 79 & 0.923 & 0.546 & 0.504 & 0.20 & 0.101 & 0.007 & 0.13 & 0.25 & 0.006 & -0.035 & -0.84 \\
\hline Mar 79 & 0.949 & 0.658 & 0.624 & 0.25 & 0.156 & 0.013 & 0.26 & 0.09 & 0.002 & -0.106 & -2.54 \\
\hline Jun 79 & 1.755 & 1.301 & 2.283 & 0.43 & 0.982 & 0.020 & 0.41 & 1.21 & 0.030 & +0.542 & +13.00 \\
\hline
\end{tabular}

Table 3. Scrobicularia plana. Calculation of scope for growth in the E. Looe population. See legend to Table 2 for details

\begin{tabular}{|c|c|c|c|c|c|c|c|c|c|c|c|}
\hline \multirow[t]{2}{*}{ Date } & \multirow{2}{*}{$\begin{array}{l}\text { Ingestion } \\
\text { rate } \\
\left(\mathrm{mg} \mathrm{h}^{-1}\right)\end{array}$} & \multirow{2}{*}{$\begin{array}{l}\text { Non- } \\
\text { refractory } \\
\text { organic } \\
\text { matter } \\
\left(\mathrm{J} \mathrm{mg}^{-1}\right)\end{array}$} & \multirow{2}{*}{$\begin{array}{l}\text { Ingested } \\
\text { ration } \\
\left(\mathrm{J} \mathrm{h}^{-1}\right)\end{array}$} & \multirow{2}{*}{$\begin{array}{l}\text { Absorp- } \\
\text { tion } \\
\text { efficiency }\end{array}$} & \multirow{2}{*}{$\begin{array}{l}\text { Absorbed } \\
\text { ration } \\
\left(\mathrm{J} \mathrm{h}^{-1}\right)\end{array}$} & \multirow{2}{*}{$\begin{array}{c}\mathrm{VO}_{2} \\
\left(\mathrm{ml} \mathrm{h}^{-1}\right)\end{array}$} & \multirow{2}{*}{$\begin{array}{c}\mathrm{VO}_{2} \\
\left(\mathrm{~J} \mathrm{~h}^{-1}\right)\end{array}$} & \multirow{2}{*}{$\begin{array}{c}\mathrm{VNH}_{4} \cdot \mathrm{N} \\
\left(\mu \mathrm{g} \mathrm{h}^{-1}\right)\end{array}$} & \multirow{2}{*}{$\begin{array}{c}\mathrm{VNH}_{4} \cdot \mathrm{N} \\
\left(\mathrm{J} \mathrm{h}^{-1}\right)\end{array}$} & \multicolumn{2}{|c|}{$\begin{array}{l}\text { Scope for } \\
\text { growth }\end{array}$} \\
\hline & & & & & & & & & & $\left(\mathrm{J} \mathrm{h}^{-1}\right)$ & $\left(\mathrm{J} \mathrm{d}^{-1}\right)$ \\
\hline \multicolumn{12}{|l|}{$\begin{array}{l}\text { Native } \\
\text { animals }\end{array}$} \\
\hline Jan 78 & 1.729 & 0.720 & 1.245 & 0.21 & 0.261 & 0.018 & 0.37 & 0.70 & 0.017 & -0.126 & -3.01 \\
\hline Apr 78 & 1.001 & 0.335 & 0.335 & 0.31 & 0.104 & 0.012 & 0.23 & 0.32 & 0.008 & -0.134 & -3.22 \\
\hline May 78 & 1.521 & 0.351 & 0.534 & 0.45 & 0.240 & 0.022 & 0.44 & 0.51 & 0.013 & -0.213 & -5.10 \\
\hline Jun 78 & 2.171 & 0.467 & 1.014 & 0.55 & 0.558 & 0.025 & 0.51 & 1.25 & 0.031 & +0.017 & +0.41 \\
\hline Aug 78 & 1.469 & 0.680 & 0.999 & 0.55 & 0.549 & 0.025 & 0.51 & 1.20 & 0.030 & +0.009 & +0.23 \\
\hline Dec 78 & 2.639 & 0.258 & 0.681 & 0.38 & 0.259 & 0.019 & 0.39 & 1.01 & 0.025 & -0.156 & -3.74 \\
\hline Feb 79 & 1.209 & 0.355 & 0.429 & 0.25 & 0.107 & 0.011 & 0.22 & 1.13 & 0.028 & -0.141 & -3.38 \\
\hline Apr 79 & 1.443 & 0.505 & 0.729 & 0.38 & 0.277 & 0.015 & 0.30 & 0.52 & 0.013 & -0.036 & -0.86 \\
\hline
\end{tabular}

Table 4. Scrobicularia plana. Calculation of scope for growth in the Gannel population. See legend to Table 2 for details

\begin{tabular}{|c|c|c|c|c|c|c|c|c|c|c|c|}
\hline \multirow[t]{2}{*}{ Date } & \multirow{2}{*}{$\begin{array}{l}\text { Ingestion } \\
\text { rate } \\
\left(\mathrm{mg} \mathrm{h}^{-1}\right)\end{array}$} & \multirow{2}{*}{$\begin{array}{l}\text { Non- } \\
\text { refractory } \\
\text { organic } \\
\text { matter } \\
\left(\mathrm{J} \mathrm{mg}^{-1}\right)\end{array}$} & \multirow{2}{*}{$\begin{array}{l}\text { Ingested } \\
\text { ration } \\
\left(\mathrm{J} \mathrm{h}^{-1}\right)\end{array}$} & \multirow{2}{*}{$\begin{array}{l}\text { Absorp- } \\
\text { tion } \\
\text { efficiency }\end{array}$} & \multirow{2}{*}{$\begin{array}{l}\text { Absorbed } \\
\text { ration } \\
\left(\mathrm{J} \mathrm{h}^{-1}\right)\end{array}$} & \multirow{2}{*}{$\begin{array}{c}\mathrm{VO}_{2} \\
\left(\mathrm{ml} \mathrm{h}^{-1}\right)\end{array}$} & \multirow{2}{*}{$\begin{array}{c}\mathrm{VO}_{2} \\
\left(\mathrm{~J} \mathrm{~h}^{-1}\right)\end{array}$} & \multirow{2}{*}{$\begin{array}{l}\mathrm{VNH}_{4} \cdot \mathrm{N} \\
\left(\mu \mathrm{g} \mathrm{h}^{-1}\right)\end{array}$} & \multirow{2}{*}{$\begin{array}{c}\mathrm{VNH}_{4} \cdot \mathrm{N} \\
\left(\mathrm{J} \mathrm{h}^{-1}\right)\end{array}$} & \multicolumn{2}{|c|}{$\begin{array}{l}\text { Scope for } \\
\text { growth }\end{array}$} \\
\hline & & & & & & & & & & $\left(\mathrm{J} \mathrm{h}^{-1}\right)$ & $\left(\mathrm{J} \mathrm{d}^{-1}\right)$ \\
\hline \multicolumn{12}{|l|}{$\begin{array}{c}\text { Native } \\
\text { animals }\end{array}$} \\
\hline Oct 77 & 3.211 & 0.441 & 1.416 & 0.51 & 0.722 & 0.020 & 0.41 & 0.51 & 0.013 & +0.299 & +7.18 \\
\hline Mar 78 & 0.949 & 0.473 & 0.449 & 0.29 & 0.130 & 0.008 & 0.16 & 0.18 & 0.004 & -0.034 & -0.81 \\
\hline Apr 78 & 1.937 & 0.322 & 0.624 & 0.30 & 0.187 & 0.021 & 0.43 & 0.52 & 0.013 & -0.256 & -6.14 \\
\hline Jun 78 & 2.639 & 0.279 & 0.736 & 0.55 & 0.405 & 0.029 & 0.59 & 0.42 & 0.010 & -0.195 & -4.68 \\
\hline Aug 78 & 2.899 & 0.292 & 0.847 & 0.50 & 0.424 & 0.024 & 0.49 & 1.56 & 0.039 & -0.066 & -1.58 \\
\hline Oct 78 & 2.951 & 0.266 & 0.785 & 0.51 & 0.400 & 0.017 & 0.34 & 0.53 & 0.013 & +0.047 & +1.14 \\
\hline $\operatorname{Jan} 79$ & 1.443 & 0.385 & 0.556 & 0.20 & 0.111 & 0.011 & 0.23 & 0.64 & 0.016 & -0.135 & -3.24 \\
\hline Apr 79 & 1.755 & 0.364 & 0.639 & 0.30 & 0.192 & 0.016 & 0.33 & 0.52 & 0.013 & -0.151 & -3.62 \\
\hline
\end{tabular}


account was taken of selectivity whilst deposit feeding, and no account was taken of the suspended particulates in the water column, although it is known that $S$ plana obtains some of its food by suspension feeding (Hughes, 1969).

The estimate of scope for growth is therefore based on several assumptions concerning ingestion rate and the utilizable food material, and in this study it can only be regarded as an approximation that will highlight the relative population and temporal differences. The scope for growth for each population was expressed in Joules $\mathrm{d}^{-1}$ (Fig. 11). Although there was

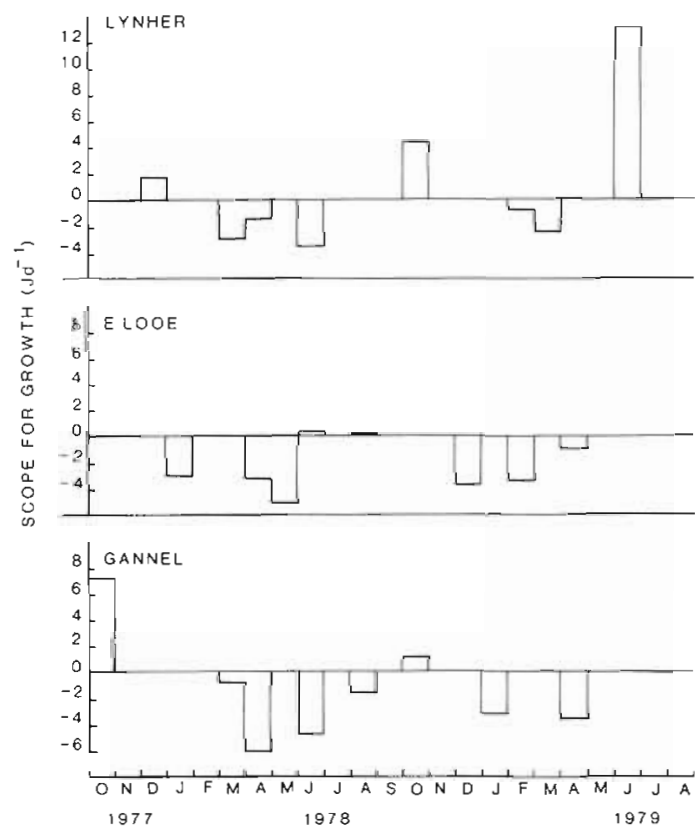

Fig. 11. Scrobicularia plana. Histogram of scope for growth $\left(J \mathrm{~d}^{-1}\right)$ based on individuals of $100 \mathrm{mg}$ dry flesh weight from the Lynher, E. Looe and Gannel populations

insufficient data on the seasonal cycle of scope for growth of Scrobicularia plana, the results showed maximum values in summer and autumn and minimum values in winter and spring. The lowest scope for growth was recorded in the Gannel population.

\section{DISCUSSION}

Oxýgen consumption $\left(\mathrm{VO}_{2}\right)$, clearance rate (CR) and ammonia excretion $\left(\mathrm{VNH}_{4} \cdot \mathrm{N}\right)$ showed a marked seasonal cycle that was not simply temperature dependent, although temperature correlated highly with $\mathrm{VO}_{2}$ in all 3 populations $(\mathrm{P}<0.001)$. Other factors such as the reproductive and nutritive storage cycles, and the quality and quantity of particulate material are known to alter the physiological responses of bivalves to seasonal environmental changes (Gabbott and Bayne,
1973; Bayne and Widdows, 1978; Bayne et al., 1979; Widdows et al., 1979). The increase in $\mathrm{VNH}_{4} . \mathrm{N}$ and corresponding decline in $\mathrm{O}: \mathrm{N}$ ratio in all 3 populations appears to be associated with gamete maturation. The elevated ammonia excretion rate by Lynher and $E$. Looe individuals during the winter, and to a lesser extent by Gannel individuals, was probably related to the post spawning recovery period, which, combined with lower feeding activity and food availability, resulted in a relative increase in protein catabolism.

Scrobicularia plana at the Gannel site had a lower body weight per unit shell length and there was less seasonal fluctuation in tissue weight, indicating a reduced growth rate and a lower fecundity compared with the Lynher or E. Looe populations. Lower tissue weight in the Gannel individuals was probably largely the result of the coarser sediment and poorer food supply; carbohydrate, protein, lipid and chlorophyll a were significantly lower here than at Lynher and E. Looe. Chlorophyll a values in the Lynher sediment were in agreement with those measured by Joint (1978) and similar values were measured at E. Looe. At these 2 sites there was a peak in late summer and early autumn, but there was no corresponding chlorophyll peak at the Gannel. Lower levels of chlorophyll $a$ at the Gannel are consistent with values found on sandy beaches (Steele and Baird, 1968) and are probably due to the mixing of the sandy sediment by wave action which maintains diatom populations at a relatively low concentration. S. plana at the Gannel partially compensated for the lower food concentration in the sediment by increasing the pumping activity and convection requirement. This physiological adaptation (an increased pumping activity without a concomitant rise in oxygen uptake) was the consequence of a morphological adaption (the higher gill area per unit tissue mass, or shell length) in the Gannel compared with the Lynher and E. Looe individuals (Fig. 9).

Scrobicularia plana at the Gannel differed from the other 2 populations, in terms of their ability to regulate $\mathrm{VO}_{2}$ in response to declining $\mathrm{pO}_{2}$. The general form of the curve for individuals from the Gannel was typical of individuals regulating their rates of oxygen consumption in spite of the reduced availability of oxygen in the environment. However, below a $\mathrm{pO}_{2}$ of $\sim 5000$ Pascals $\left(\sim 40 \mathrm{~mm} \mathrm{Hg}\right.$ ) regulation had ceased and $\mathrm{VO}_{2}$ had become linearly dependent on $\mathrm{pO}_{2}$. The degree of oxy-regulation shown by $S$. plana from the Gannel was probably a consequence of the larger gill area and higher pumping rates, primarily associated with feeding, which enabled more oxygen to be made available to the bivalve. Bivalves normally experiencing hypoxia have a higher degree of repiratory independence and maintain their $\mathrm{VO}_{2}$ over a wider range of external $\mathrm{pO}_{2}$ by compensatory adjustments of ventila- 
tion rate and oxygen extraction efficiency. However, Bayne (1973) has shown that the bivalves Anadara, Geloina and Mytilus also have a reduced capacity to regulate $\mathrm{VO}_{2}$ in declining $\mathrm{pO}_{2}$ at low salinity, which is reflected in an increase in the ratio $K_{1} / K_{2}$. Therefore the higher $K_{1} / K_{2}$ ratios of $S$. plana from the Lynher and E. Looe may be due in part to the lower salinities at these sites.

Reproductive cycles of Scrobicularia plana at the Lynher and E. Looe sites were similar but at the Gannel the developmental period was shorter, the gametes matured quicker and the bivalves spawned earlier (Fig. 5). It has been demonstrated experimentally with other bivalves that gametogenesis may be initiated by temperature increase but only if sufficient nutrient reserves have been built up or if there is adequate food available in the environment (Sastry, 1968, 1970; Bayne, 1975). Gametogenic development in S. plana was initiated in Aprii./May at the time of increasing temperature and food supply in the water column and to a lesser extent in the sediment, and the maturation of gametes in the Lynher and E. Looe individuals coincided with the peak of available food in the sediment (Fig. 4). In the Gannel, however, where there was less food available and little seasonal change in the sediment composition, the growth and reproduction of $S$. plana may have been more dependent on the algal spring bloom in the water column. At the Gannel site, an adequate food supply was probably available for a much shorter time than at the Lynher and E. Looe, necessitating a more rapid gamete development and culminating in an earlier spawning.

The results of the study have demonstrated significant physiological differences between 3 populations of Scrobicularia plana. A major environmental factor determining these interpopulation differences in the functioning and performance of $S$. plana at the 3 sites was probably the food supply.

In order to investigate the plasticity of the physiological responses and the possible factors determining the recorded population differences bivalves were transplanted between the 3 sites. This aspect of the study has been described in the following paper (Worrall and Widdows, 1983).

Acknowledgements. We are grateful to Dr. B. L. Bayne for helpful discussions and critically reading the manuscript. We are also indebted to Dr. K. R. Clarke for statistical guidance, Dr. E. I. Hamilton for microscopic analysis of sediment, and to the late Miss C. F. Hawke for the illustrations. This work forms part of the experimental ecology programme of the Institute for Marine Environmental Research, a component of the Natural Environmental Research Council. It was commissioned in part by the Department of the Environment (Contract No. DGR 480/683).

\section{LITERATURE CITED}

Bancroft, J. D. (1967). An introduction to histochemical technique. Butterworth, London

Bayne, B. L. (1971a). Oxygen consumption by three species of Lamellibranch Molluscs in declining ambient oxygen tension. Comp. Biochem. Physiol. 40A: 955-970

Bayne, B. L. (1971b). Ventilation, the heart beat and oxygen uptake by Mytilus edulis L. in declining oxygen tension. Comp. Biochem. Physiol. 40A: 1065-1085

Bayne, B. L. (1973). The response of three species of bivalve molluscs to declining oxygen tension at reduced salinity. Comp. Biochem. Physiol. 45A: 793-806

Bayne, B. L. (1975). Reproduction in bivalve molluscs under environmental stress. In: Vernberg, F. J. (ed.) Physiological ecology of estuarine organisms. University of South Carolina Press, Columbia, p. 259-277

Bayne, B. L. (ed.) (1976). Marine Mussels, their ecology and physiology. Cambridge University Press, London

Bayne, B. I., Moore, M. N., Widdows, J., Livingstone, D. R., Salkeld, P. (1979). Measurement of the response of individuals to environmental stress and pollution: studies with bivalve molluscs. Phil. Trans. R. Soc. (B). 286: 563-581

Bayne, B. L., Widdows, J. (1978). The physiological ecology of two populations of Mytilus edulis L. Oecologia (Berl.) 37 : $137-162$

Bayne, B. L., Widdows, J., Worrall, C. M. (1977). Some temperature relationships in the physiology of two ecologically distinct bivalve populations. In: Vernberg F.J., Calabrese A., Thurberg F. P., Vernberg W. B. (ed.) Physiological responses of marine biota to pollutants. Academic Press, London, p. 379-400

Bayne, B. L., Worrall, C. M. (1980). Growth and production of mussels Mytilus edulis form two populations. Mar. Ecol. Prog. Ser. 3: 317-328

Boyden, C. R. (1977). Effect of size upon metal content of shellfish. J. mar. biol. Ass. U. K. 57: 675-714

Bryan, G. W. (1971). The effect of heavy metals (other than mercuryj on marine and estuarine organisms. Proc. R. Soc. (B) $177: 389-410$

Bryan, G. W., Hummerstone, L. G. (1977). Indicators of heavy metal contamination in the Looe estuary (Cornwall) with particular regard to silver and lead. J. mar. biol. Ass. U. K. 57: 75-92

Bryan, G. W., Hummerstone, L. G. (1978). Heavy metals in the burrowing bivalve Scrobicularia plana from contaminated and uncontaminated estuaries. J. mar. biol. Ass. U. K. 58: $401-419$

Bryan, G. W., Langston, W. J., Hummerstone, L. G. (1980). The use of biological indicators of heavy metal contamination in estuaries with special reference to an assessment of the biological availability of metals in estuarine sediments from south-west Britain. Marine Biological Association of the United Kingdom, Occ. Publ. No. 1

Bryan, G. W., Uysal, H. (1978). Heavy metals in the burrowing bivalve Scrobicularia plana from the Tamar estuary in relation to environmental levels. J. mar. biol. Ass. U. K. 58 : 89-108

Bubnova, N. P. (1972). The nutrition of the detritus feeding molluscs Macoma balthica (L.) and Portlandia arctica (Gray) and their influence on bottom sediments. Oceanology 12: 899-905

Buchanan, J. B., Kain, J. M. (1971). Measurement of the physical and chemical environment. In: Holme, N. A., McIntyre, A. D. (ed.) Methods for the study of marine benthos. IBP Handbook, No. 16. Blackwell, Oxford, p. 30-58

Cammen, L. M. (1980). Ingestion rate: an empirical model for 
aquatic deposit feeders and detritivores. Oecologia (Berl.) 44: $303-310$

Conover, R. J. (1966). Assimilation of organic matter by zooplankton. Limnol. Oceanogr. 11: 338-354

Corner, E. D. S., Cowey, C. B. (1968). Biochemical studies on the production of marine zooplankton. Biol. Rev. 43: $393-426$

Coughlan, J. (1969). The estimation of filtering rate from the clearance of suspensions. Mar. Biol. 2: 356-358

Culling, C. F. A. (1963). Handbook of histopathological techniques. Butterworth, London

Gabbott, P. A., Bayne, B. L. (1973). Biochemical effects of temperature and nutritive stress on Mytilus edulis L. J. mar. biol. A.ss. U. K. 53: 269-286

Gilfillan, E. S. (1975). Decrease of net carbon flux in two species of mussels caused by extracts of crude oil. Mar. Biol. 29 (1): $53-58$

Gilfillan, E. S., Mayo, D. W., Page, D. S., Donovan, D., Hanson, S. (1977). Effects of varying concentrations of petroleum hydrocarbons in sediments on carbon flux in Mya arenaria. In: Vernberg, F. J., Calabrese, A., Thurberg, F. P., Vernberg, W. B. (ed.) Physiological responses of marine biota to pollutants. Academic Press, New York, p. 299-314

Gilson, W. E. (1963). Differential respirometer of simplified and improved design. Science, N. Y. 141: 531-532

Grasshoff, K., Johannsen, H. (1972). A new sensitive and direct method for the automatic determination of ammonia in seawater. J. Cons. int. Explor. Mer 34 (3) : 516-521

Hughes, R. N. (1969). A study of feeding in Scrobicularia plana. J. mar. biol. Ass. U. K. 49: 805-823

Hughes, R. H. (1970). An energy budget for a tidal-flat population of the bivalve Scrobicularia plana (Da Costa). J. Anim. Ecol. 39: 357-381

Joint, I. R. (1978). Microbial production of an estuarine mudflat. Estuar. coast. mar. Sci. 7: 185-195

Lowe, D. M., Moore, M. N., Bayne, B. L. (1982). Aspects of gametogenesis in the marine mussel Mytilus edulis. J. mar. biol. Ass. U. K. 62:133-145

Sastry, A. N. (1968). Relationships among food, temperature and gonad development of the bay scallop. Aequipecten irradians Lamarck. Physiol. Zool. 41: 44-53

Sastry, A. N. (1970). Environmental regulation of oocyte growth in the bay scallop Aequipecten irradians Lamarck. Experientia 26: 1371-1372

Solorzano, L. (1969). Determination of ammonia in natural waters by the phenolhypochlorite method. Limnol. Oceanogr. 14: 799-801

Steele, J. H., Baird, I. E. (1968). Production ecology of a sandy beach. Limnol. Oceanogr. 13: 14-25

Tang, P.S. (1933). On the rate of oxygen consumption by tissues and lower organisms as a function of oxygen tension. Q. Rev. Biol. 8: 260-274

Taylor, A. C., Brand, A. R. (1975). A comparative study of the respiratory responses of the bivalves Arctica islandica (L.) and Mytilus edulis (L.) to declining oxygen tension. Proc. R. Soc. (B.) 190: 443-456

Umbreit, W. W., Burris, R. H., Stauffer, J. F. (1964). Manometric techniques, 4 th ed. Burgess Publ. Co., Minneapolis

Warren, C. E., Davis, G. E. (1967). Laboratory studies on the feeding bioenergetics and growth of fish. In: Gerking, S. D. (ed.) The biological basis of freshwater fish production. Blackwell, Oxford, p. 175-214

Warwick, R. M., Price, R. (1975). Macrofauna production in an estuarine mud-flat. J. mar. biol. Ass. U. K. 55: 1-18

Widdows, J., Fieth, P., Worrall, C. M. (1979). Relationships between seston, available food and feeding activity in the common mussel Mytilus edulis. Mar. Biol. 50: 195-207

Winberg, G. G. (1960). Rate of metabolism and food requirements of fish. Fish Res. Bd Can., Trans. Ser. 194: 1-202

Worrall, C. M., Widdows, J. (1983). Physiological changes following transplantation of the bivalve Scrobicularia plana between three populations. Mar. Ecol. Prog. Ser. 12: 281-287 